\title{
Melancholy and Creativity in Petrarch
}

Much has been written on the Renaissance concept of melancholy in its relationship with genius and creativity. From Klibansky's, Panofsky's and Saxl's Saturn and Melancholy to Lawrence Babb's Elizabethan Malady, Rudolf and Margot Wittkower's Born under Saturn, Bridget Lyons' Voices of Melancholy, Winfried Schleiner's Melancholy, Genius, and Utopia in the Renaissance, Jennifer Radden's The Nature of Melancholy from Aristotle to Kristeva, Noel Brann's The Debate over the Origin of Genius during the Renaissance, Jen Webb's "Depression and Creative Writing Students," and the recently published Passions and Tempers by Noga Arikha-just to mention some of the studies published in English-almost every angle of the problem has been investigated.

The founding text is the first problem of section XXX of the Problemata attributed until recently to Aristotle. The problem begins with the question: "Why is it that all those who have become eminent in philosophy or politics or poetry or the arts are clearly melancholics and some of them to such an extent as to be affected by diseases caused by black bile?" In other words, melancholy is the precondition of genius. In explaining the reasons, the author of the problem (probably Theophrastus) adds a further dimension to genial melancholy, the gift of divination: "Many too are subject to fits of exaltation and ecstasy, because this heat is located near the seat of the intellect; and this is how Sibyls and soothsayers arise, and all that are divinely inspired, when they become such not by illness but by natural temperament"(XXX.1 953a10-16). This principle, already stated by Aristotle in his De insomniis vel de divinatione [ $463 \mathrm{~b}$ 17] will be repeated by Cicero in his De divinatione and later espoused by Marsilio Ficino in his De vita libri tres at the center of the Florentine Platonic revival.

However, it is not my intention to expound this theory with all its twists and turns-Platonists against Aristotelians, physici against philosophers, melancholy and heroic or heroical love-from a casual, but from a causal point of view. In other words, while the history of the concept has been minutely traced by a large number of of studies, no one-to my knowledge at least-has examined the psycho-physiological mechanisms that underscore the relationship between melancholy and geniality. And if these mechanisms can be identified and explained, can we consider them valid also for poetic creativity, and can we apply them to a poet such as Petrarch to better understand certain aspects of his poetry?

Massimo Ciavolella, University of California Los Angeles

D Open Access. () 2020 Massimo Ciavolella, published by De Gruyter. (c) BY-NC-ND This work is licensed under a Creative Commons Attribution-NonCommercial-NoDerivatives 4.0 International License.

https://doi.org/10.1515/9783110615937-012 
I will discuss the problem of artistic/poetic creativity by first examining the role of imagination or phantasia, and that of the phantasmata, in the creative process moved by melancholy, and I will explore the central role of phantasmata as a hinge between melancholy engendered by desire and the creative process. I will also show that this approach will offer us an illuminating way to understand a dilemma central to Petrarch's poetry: the propensity to conflate desire with the good. I will begin with the insight that got me started in this investigation, that is to say when I asked myself why, in his Speculum phisionòmie (1442) the physician Michele Savonarola (1385-1466) writes that many artists can only create when provoked by melancholy, and gives the example of certain singers and instrumentalists who refuse to make music "unless they first are moved by phantasmata". These artists-he explains-are deemed by many bizarios, eccentrics, but they are in truth melancholics moved by a fixed imagination. ${ }^{1}$

And what does the painter Romano Alberti (ca. 1555-1604) mean in his Trattato della nobiltà della pittura (published in 1585) when he writes:

...li pittori divengono malencolici, perché volendo loro imitare bisogna, che ritenghino li fantasmati fissi nell'Intelletto accio dipoi li esprimeno in quel modo, che prima li havean visti in presentia: Et questo non solo una volta, ma continuamente, essendo questo il loro essercitio; per il che talmente tengono la mente astratta et separata dalla materia, che conseguentemente ne vien la Malencolia; la quale però dice Aristotile, che significa ingegno et prudentia, perché, come l'istesso dice quasi tutti gl'ingegnosi et prudenti son stati malencolici. ${ }^{2}$

(... painters become melancholics because, wishing to imitate, they must retain the phantasms fixed in the intellect, so that afterward they can express them in the way they first saw them when present; and this not only once, but continuously, since this is their occupation. Because of this they keep their minds so much abstracted and separated from nature that consequently melancholy derives from it, which, Aristotle says, signifies genius and prudence since, as he himself says, almost all genial and prudent persons have been melancholics.)

As already mentioned, I will try to offer a possible explanation by going back to Petrarch's Canzoniere and to his Secretum, and to the pre-modern psychophysiological theories that were thought to control perception, passions, and creativity.

One of the leitmotifs of Petrarch's Canzoniere-arguably the most influential collection of poems in Western literature-is the overwhelming power of Laura's image. Let's take a few sonnets, chosen at random: ${ }^{3}$

1 Quoted by N. L. Brann, The Debate over the Origin of Genius during the Renaissance, Leiden 2012, 22.

2 R. Alberti, Trattato della nobiltà della pittura, published by F. Zannetti, Rome 1585. The quotation comes from 17-18.

3 I have used the edition of Petrarch's Canzoniere, M. Santagata (ed.), Milan 1996. 


\section{LXXXIII}

Se bianche non son prima ambe le tempie ch'a poco a poco par che 'l tempo mischi, securo non sarò, bench'io m'arrischi talor ov'Amor l'arco tira et empie.

Non temo già che più mi strazi o scempie, né mi ritenga perch'ancor m'invischi, né m’apra il cor perché di fuor l'incischi con sue saette velenose et empie.

Lagrime omai dagli occhi uscir non ponno, ma di gire infin là sanno il viaggio, sì ch'a pena fia mai ch'i' 'l passo chiuda.

Ben mi pò riscaldare il fiero raggio, non sì ch'i' arda; e può turbarmi il sonno, ma romper no, l'imagine aspra e cruda.

\section{CVII}

Non veggio ove scampar mi possa omai: sì lunga guerra i begli occhi mi fanno, ch'i' temo, lasso, no 'l soverchio affanno distruga 'l cor che triegua non à mai.

Fuggir vorrei: ma gli amorosi rai, che dì et notte ne la mente stanno, risplendon sì, ch'al quintodecimo anno m'abbaglian più che 'l primo giorno assai;

et l'imagine lor son sì cosparte che volver non mi posso, ov'io non veggia o quella o simil indi accesa luce.

Solo d'un lauro tal selva verdeggia che 'l mio adversario con mirabil arte vago fra i rami ovunque vuol m'adduce.

\section{CXVI}

Pien di quella ineffabile dolcezza che del bel viso trassen gli occhi miei nel dì che volentier chiusi gli avrei per non mirar già mai minor bellezza,

lassai quel ch'i' più bramo; et ò sì avezza la mente a contemplar sola costei, ch'altro non vede, et ciò che non è lei già per antica usanza odia et disprezza.
If both my temples aren't soon all white air Which bit by bit it seems that time blends in, I shall not rest secure, though I at times Take risks where love draws back and arms his bow.

Indeed, I do not fear that he can hurt Me more, destroy, nor capture me because I still am snared, nor split my heat since it's Still pierced with his darts, wicked, poisonous.

No tears henceforth can issue from my eyes, Though having gone that far, the path thry know,

Thus it is hard to bar their way at all.

Indeed, the cruel ray can make me hot Yet not burn me; that image harsh and hard Can trouble sleep, but cannot break it off.

Henceforth I see no way I can be saved; So long her lovely eyes make war on me That now I fear, ah woe, lest pain too great Lay waste my heart, which never has a truce.

I'd like to flee; yet still the amorous rays That, day and night, stays in my memory Blaze so that in this fifteenth year much more They dazzle me than that first day they did;

Their images are scattered so about That nowhere can I turn that I don't see That light, or else its likeness, kindled thence.

From just one laurel, such a forest thrives That with amazing art my foe leads me Astray amidst the brances, where he will.

Filled with that sweetness inexpressible That from her lovely face my eyes drew forth, That day when I'd have closed them willingly To gaze no more on lesser loveliness,

I left what most I yearn for, and have schooled My mind to contemplate her only, so It seems no other, and what is not she, Indeed by custom old it loathes and scorns. 
In una valle chiusa d'ogni 'ntorno, ch'è refrigerio de' sospir' miei lassi, giunsi sol cum Amor, pensoso et tardo.

Ivi non donne, ma fontane et sassi, et l'imagine trovo di quel giorno che 'l pensier mio figura, ovunque io sguardo.

\section{CXXX}

Poi che 'l camin m'è chiuso di Mercede, per desperata via son dilungato da gli occhi ov'era, i' non so per qual fato, riposto il guidardon d'ogni mia fede.

Pasco 'l cor di sospir', ch'altro non chiede, et di lagrime vivo a pianger nato: né di ciò duolmi, perché in tale stato è dolce il pianto più ch'altri non crede.

Et sol ad una imagine m'attegno, che fe' non Zeusi, o Prasitele, o Fidia, ma il miglior mastro, et di più alto ingegno.

Qual Scithia m'assicura, o qual Numidia, s'anchor non satia del mio exilio indegno così nascosto mi ritrova Invidia?
Into a valley closed on every side Where there is solace for my weary sighs, Pensive and slow I went alone with Love.

No ladies there, but rather founts and stones I find, and find in every place I look

The likeness of that day which shapes my [thoughts

Since Mercy's path is barred to me, along A desperate road I've wandered, far from eyes In which, I know not by what destiny, Was stored up the reward of all my faith.

On sighs I feed my heart, it asks naught else; On tears I live, and am to weeping born; Nor do I grieve at that; in such a plight Complaint is sweeter that one might believe.

To just one image I pay heed, not made By Zeuxis, Phidias, or Praxiteles, But by a master greater, with more skills.

What Scythia or what Numidia Can save me if, not sated yet with my Base exile, Envy finds me hidden so?

The first impression we derive from reading these sonnets is that their main theme is that of the grief of love, one of the most common and abused topics in western literature from Sappho onwards. However, at a closer reading the real leitmotif comes to light: the obsessive, everlasting presence of Laura's image, its overwhelming power. Scholars have stressed the fundamental importance of the theme of the formation and function of the image of Laura in the love lyrics of the Canzoniere, and have gone back to Thomas Aquinas and Saint Augustine to explain its role in Petrarch's conception of erotic passion. For example, in order to explain four of Petrarch's most famous sonnets (125, "Se 'l pensier che mi strugge"; 126, "Chiare fresche e dolci acque"; 127, "In quella parte dove Amor mi sprona," and 129, "Di pensier in pensier, di monte in monte") Italian critic Adelia Noferi has made two observations about a set of Petrarch's sonnets that also applies to my selection: "Tutte e quattro ruotano intorno ad uno stesso nodo tematico: 1) l'assenza-presenza di lei, di Laura, l'oggetto d'amore; la formazione e la funzione dell'immagine di lei (nell'accezione agostiniana di fantasma)."

4 A. Noferi, “Canzone CXXVII”, in Lectura Petrarce, Florence 1982, 3-20. Cf. also R. Caputo, Cogitans fingo. Petrarca tra "Secretum" e “Canzoniere”, Rome 1987. 
(All [of them] rotate around the same thematic core: 1) the absence/presence of Laura, the object of love; 2) the formation and function of the image of Laura (in the Augustinian meaning of 'phantasm')." To Noferi's two observations, I would add a third, and a crucial one for the main point I will be making: the diatribe against the phantasmata, which has been spelled out in the Secretum, an imaginary conversation between two interlocutors, one named Franciscus, modeled on Petrarch, and the other Augustinus, modeled on the Latin church Father Augustine [354-430]. In the first book of the dialogue Augustinus warns Franciscus:

Rite discernis, atqui verificatum est in vobis illud apostolicum: “Corpus, quod corrumpitur, aggravate animam, et deprimit terrena inhabitation sensum multa cogitantem”. Conglobantur siquidem species innumere wt imagines rerum visibilium, que corporeis introgresse sensibus, posquam singulariter admisse sunt, catervatim in anime penetralibus densantur; eamque, nec ad id genitam nec tam multorum difformiumque capacem, pregravant atque confundunt. Hinc pestis illa fantasmatum vestros discerpens laceransque cogitates, meditationibusque clarificis, quibus ad unum solum summumque lumen ascenditur, iter obstruens varietate mortifera. ${ }^{5}$

(You perceive this rightly, and the words of the apostle are verified by our experience: "The body, which is corrupt, aggravates the soul, and earthly existence presses in on the mind, which is taking in many things." For innumerable shapes and images of visible things, which entered through the bodily senses one at a time, come together and crowd into the innermost parts of the soul. And the soul, not made for this and not able to take in so many different images, gets weighed down and confused. And so that plague of apparitions [phantasmata] rips and mangles your thinking, and with its fatal multiplicity obstructs the way to illuminating meditation, through which we are raised up to the one and only highest light.)

The role of phantasy-phantasia-is one of the essentials points of Augustinus' diatribe against Franciscus. In the second book, to Augustinus' question: "Well, to what degree have you been consumed by the flames of lust?" Franciscus replies: "Enough so that I have at times lamented that I was not born without feelings. I would prefer to be an insensate stone than to be undone by so many impulses in my body." Augustinus' rebuke is harsh and direct:

Habes igitur quod te vel maxime ad omni divinorum cogitatione dimoveat. Quid enim aliud celestis doctrina Platonis admonet, nisi animum ad libidinibus corporeis arcendum et eradenda fantasmata, ut ad pervidenda divinitatis archana, cui proprie mortalitatis annexa cogitation est, purus expeditusque consurgat? Scis quid loquor, et hec ex Platonis libris tibi familiariter nota sunt, quibus avidissime nuper incubuisse diceris. ${ }^{6}$

5 Secretum, ed. G. Ponte, Milan 1968, I, 471.

6 Secretum, 1. II, 498-500. 
(There you have it, the thing that mostly drives you away from all meditation on divine things. For what does the heavenly teaching of Plato demonstrate if not that the soul must be kept away from the bodily desires and that images of earthly things must be eradicated so that the soul can rise, pure and free, to examine the mysteries of the divine, to which it joins a contemplation of its own mortality? You recognize what I am saying, and these ideas from Plato's books are known and familiar to you. Indeed, you are said to have recently devoted yourself more eagerly to the study of these books.)

The battle-and it is interesting to note that in order to illustrate the aggressive motion of the phantasms Petrarch uses a military metaphor-is not against phantasms per se (nor could it be, as we will see later), but against a "confused" state of mental images, and especially against their role in generating perverted and perverting images fueled by excessive desire.

I will first summarize briefly the pre-modern concept of passions in general, and erotic passion in particular, as a preamble to my discussion of the mechanisms whereby phantasms play a decisive role in the generation of confusion or perversion according to views that would have directly informed Petrarch's poetry. I realize that some of you are quite familiar with these concepts, but please bear with me: I'll be succinct. ${ }^{7}$

The theory is founded upon the system of the faculties or powers (virtutes) of the soul developed by Aristotle and especially by the second century CE Claudius Galenus, and later inherited by Arabic and scholastic medicine. According to this system, to the three parts of the soul-1: The rational; 2: The one controlling passions; 3: The one that regulates appetites-correspond certain powers, certain faculties that distinguish the activities proper to that part of the soul: the animal faculties in the brain; the vital powers in the heart; the natural ones in the liver (power of nutrition) and in the testicles (power of generation). The animal faculties are those which allow human beings to perceive, to apprehend and know the reality that surrounds them by means of the five external senses and the corresponding internal senses located in the brain: the "common sense," the "phantasia," the "power of cogitation," the "power of estimation," the "power of conservation and memory." The vital and natural faculties are, on the other hand, strictly bound to the body and are shared also with animals (the vital faculties), and to with plants (the natural faculties).

7 For a more thorough discussion on this topic, in addition to my old La "malattia d'amore" dall'Antichità al Medioevo, Rome 1976, see also M. F. Wack, Lovesickness in the Middle Ages. The "Viaticum" and Its Commentaries, Philadelphia 1986; I. P. Couliano, Eros and Magic in the Renaissance, M. Cook (transl.), Chicago 1987, originally published in France under the title I. P. Couliano, Eros et magie à la Renaissance, 1484, Paris 1984; and the D. Beecher and M. Ciavolella, “Introduction”, in J. Ferrand, De la maladie d'amour ou mélancolie érotique, Paris 2010. 
The well being of every human being is controlled by the pneuma, or spirits, for they provide that essential link between the body and the soul. The spirits are the instruments of the faculties and correspond to the three parts of the souls: the natural, the vital, and animal (animus) parts. The natural spirit is generated in the liver from pure blood, and from the liver it circulates to all parts of the body through the veins. The vital spirit comprises two elements: inhaled air and the exhalations of the blood. These two elements are blended in the heart as soon as the air has been transformed and purified in the lungs through a process quite similar to digestion. From the left ventricle of the heart, the vital spirit is passed to the arteries and to what was called the "retiform plexus" at the base of the brain, where it undergoes a further transformation. Finally, it enters the lateral ventricles of the brain where it joins with the air inhaled through the nostrils; the result is the animal spirit that occupies the major ventricle of the brain, the parencephalon. This spirit performs all the operations required by the rational soul and controls, through the nerves, the sensory activities of man, as well as voluntary motion.

In short, in every human being there are three vital centers: the liver, the heart, and the brain. From these centers an interlacing network of vital currents branches out across the body by means of the veins, arteries, and nerves. These vital currents are critical to the efficiency and wellbeing of the organism. Being formed of air and blood, they are susceptible to changes in the internal balance of the humors as well as to external conditions such as atmospheric pressure.

The psychological process must be understood to operate by means of this pneumatic circulation. Avicenna, in the De anima, explains in these terms the process through which the form of the object passes from the external senses to the internal powers of the soul:

... unitur ... forma similitudinaria una penes partem spiritus qui gestat virtutem videndi. Deinde ... penetrat in spiritum qui est repositus in primo ventriculo cerebri, et imprimatur iterum forma visa in ipso spirit qui est gerens virtutem sensus communis ... Deinde haec virtus quae est sensus communis reddit formam alii parti spiritus, quae est continua cum parte spiritus quae vehit ipsum, et imprimit in illam formam ipsam, et repoint eam ibi apud virtutem formalem, quae est imaginativa, sicut postea scies, quae recipit et conservat eam. Sensus etenim communis est recipiens formam, sed non retinens; imaginativa vero retinet quod recipit illa.... Deinde forma quae est in imagination penetrat posteriorem ventriculum ... et coniungetur forma cum spiritu qui gerit virtutem aestimativam, quae vocatur in hominibus virtus cogitationis, et forma quae erat in imaginativa imprimatur in spiritu virtutis aestimationis....

8 Avicenna (Ibn Sina), Avicenna Latinus, Liber de anima seu Sextus de Naturalibus, ed. S. Van Riet, volume I, Louvain 1972, III.8, 268-70. 
(... the similitude [of the object] is fused with the spirit that carries the power of vision. Then ... it penetrates into the spirit that is located in the first ventricle of the brain, and is then imprinted upon this spirit, which is the one that carries the power of the $\mathrm{com} \mathrm{mon}$ sense.... Then this power that is the common sense transmits the form to the neighboring spirit, imprinting it with the form, and thereby places the object in the imaginative poweras you will later learn-that which receives and keeps forms.... Then the form that is in the imagination enters into the posterior ventricle of the brain ... and unites itself with the spirit that carries the power of estimation, called in men cogitative power, and the form that was in the imaginativa imprints itself upon the spirit of the power of estimation.)

The birth of desire is bound to a natural alteration of the body's innate heat due to the sight of a person (or an object) perceived as pleasant. Desire generates heat; heat determines an exponential increment of the humors of the body, especially of black bile, melancholy. When the image of an object perceived as pleasant reaches the internal faculties of the soul, the vital spirits, because of the sudden pleasure, multiply. This multiplication of spirits generates more heat, which by nature expands upwards. As a consequence the vital spirits, from the left ventricle of the body, where they are located, expand upwards throughout the body, overheating the natural and animal spirits. The receptacle of the power of estimation-that is to say the dorsal part of the middle ventricle of the brain, being in contact with the overheated spirits rising from the heart, also overheats. The permanence of images, of the "phantasmata" of perception is directly proportional to the level of inflammation of the receptacle itself.

The faculty of estimation controls that of imagination and the permanence of images entered through the senses-that is to say the permanence of the phantasmata in the "virtus imaginativa" or "phantasia"-depends upon the degree of dryness of the ventricles of the brain. The overheating of the faculty of estimation caused by the overheating of phantasia causes an evaporation of the radical humor determining a condition of excessive dryness. This process of physiological derangement generates a sudden and excessive increase of the melancholic humor-dry and cold-that enters the cavities of the brain and fixes the image of the object of desire in the organ of imagination and of memory, polarizing the whole attention of the animal soul, of the brain. This brief passage comes from Arnaldus de Villanova's treatise De amore heroico:

Ex predictis iterum elicere convenit propter quod imaginativa fixa sicpermanet circa rem, unde talem gratum anima preconcepit; oportet enim similiter ex organi vitio seu aliqua malitia. Cum itaque firma retention formarum in multis quibuslibet nequaquam effici valeat sino sicco, necessario sequitur cerebellarem partem imaginative virtutis aliqualiter exsiccari. Hoc vero ex pretactis sic ostenditur: cum et fortis et frequens sit transitus calidorum spirituum ad cellam estimative fluentium ad iudicium celebrandum, pars anterior in qua virtus imaginativa residet propter humidi consumptionem a calore spirituum derelict remanet necessario siccior seu minus humida quam fuerit per naturam. Hac igitur 
introducta qualitate, sequitur-maxime si aliqua frigiditas coniugatur-quod forma imaginationis in organo firmius retinetur necnon multa sollicitudo validius excitatur. ${ }^{9}$

(From what I have said before we can deduce the reason why the faculty of imagination remain fixed upon the object-this is the reason why the soul imagines it as a pleasant one ahead of time [i.e., before it actually knows it]... Since solid retention of images can only happen when there is a dry condition, it follows that the cerebral part of the imaginativa becomes notably dry. We can prove this in the following manner: since the transit of the warm spirits which flow towards the cell of estimation to take care of the act of cogitation is strong and frequent, the anterior part [of the brain]-in which the power of imagination residesbecause of the consumption of humidity, due to the heat of the spirits, becomes more dry and less humid than usual. What follows is that, if a cold element enters into the imaginativa, the image, which is in the organ of imagination, remains solidly fixed within the organ.)

\section{"Necnon-Arnaldus concludes-multa sollicitudo validius excitatur."}

According to pre-modern natural philosophy, phantasia and the phantasma occupy an essential role in the cognitive process because the body was believed to be simply a form of organization of the natural elements. Without the vitality that the soul guarantees, the body would immediately break apart. Soul and body are by nature completely unaware one of the other, just like they are blind of each other's sphere of influence. "The soul has no ontological aperture through which it can look down." In turn, the body, that is to say matter, cannot communicate by itself with the soul. The instrument, the proton organon that allows the soul to communicate with the body is the pneuma, the spirit. Being made of the same substance of which stars are made, it is ethereal enough that it comes close to the immaterial nature of the soul. At the same time, being a body, it can come into contact with the sensible world. The soul transmits to the body the vital activities through the proton organon, that is to say the spiritual apparatus located in the heart. In turn "the body opens up to the soul a window to the world through the five sensory organs .... Called phantasia, or inner sense, the sidereal spirit transforms messages from the five senses in phantasms perceptible to the soul."10 In fact, the souls cannot operate without phantasmata. Guillaume de Moerbecke translates the passage in which Aristotle sets this fundamental concept in these words: "Nunquam sine phantasmate intelligit anima." ${ }^{11}$ Saint Thomas Aquinas appropriates this very concept in his Summa Theologica, where he writes: "Intelligere sine conversione ad phantasmata est [animae] praeter naturam."12 Ioan Couliano writes:

9 "De amore heroico", in M. McVaugh (ed.), Opera medica omnia, volume II, Barcelona 1985, 50. 10 Couliano, Eros and Magic, 4-5.

11 De anima, 432a.

12 Summa Theologica, I.q.89.a.1.,c. 


\begin{abstract}
Fundamentally, all is reduced to a question of communication: body and souls speak two languages, which are not only different, even inconsistent, but also inaudible to each other. The inner sense alone is able to hear and comprehend them both, also having the role of translating one into the other. But considering the words of the soul's language are phantasms, everything that reaches it from the body-including distinct utterances, will have to be transposed into a phantasmic sequence. Besides-must it be emphasized?-the soul has absolute primacy over the body. It follows that the phantasm has absolute primacy over the word, that it precedes both utterance and understanding of every linguistic message. Whence two separate and distinct grammars, the first no less important than the second: a grammar of the spoken language and a grammar of phantasmic language. Stemming from the soul, itself phantasmic in essence, intellect alone enjoys the privilege of understanding the phantasmic grammar. It can make manuals and even organize very serious-minded games of phantasms. But all that will be useful to him principally for understanding the soul and investigating its inner potentiality. ${ }^{13}$
\end{abstract}

What this means is that, under the best conditions, desire resides within memory as a species intelligibilis of the object of desire, and in the sensitive appetite as a phantasma of the imagination. But if the desire grows unchecked, melancholy fixes the image in the organ of imagination and of sensitive memory, and it becomes the only "good" present to the consciousness of the lover, a perverted image of a form, which can never become an object of intellection.

The fundamental contradiction of excessive desire consists in this: the complexio venerea fixes the image in the sensitive memory of the soul. And since it is the only presence in the consciousness of the lover because of the perversion of the process of intellection, the phantasma is identified with the true "Good." In other words, the Good, which should be the only true object of human desire, is confused and identified with the phantasma, with the image of an object of sensual desire. The melancholy delirium that arises from this perversion of the internal senses drags the lover in a quest for an image which is permanently reflected in memory, in a vain, obsessive attempt to possess an object of desire which can never be possessed or reached, because it has become a true figment of the imagination.

If I have been successful in leading you on the journey in search of the correlation between melancholy, artistic creativity, and erotic desire, then the statements of Michele Savonarola and Romano Alberti-and I could have added Guido Cavalcanti's great poem “Donna me prega," Pietro D’Abano's Acerba, Marsilio Ficino's De vita libri tres or Giovanni Battista della Porta's De humana physiognomonia and many others-why those statements with which I opened my talk, on why

13 Couliano, Eros and Magic, 4-5. 
artistic creativity can only be born under the sign of Saturn, should be somewhat clearer. $^{14}$

The psycho-physiological process I summarized helps us explain, I believe, Augustinus' diatribe, in the Secretum, against the phantasmata of excessive desire, and especially against the obsessive image of Laura in the lyrics of the Canzoniere. The only language, the only grammar present in the verses of the poems is that of desire. In other words, if the phantasma has an absolute prominence over the word, it follows that the fixation of the image within the organ of imagination has a language, a grammar which is bound to that particular phantasm, and which excludes the possibility of any other form of knowledge. Thus, the poetic language becomes a function of that phantasmatic image, and the poetic "I" remains confined within an obsessively morbid melancholy spiral: the words are a function of the image; the image is that of Laura, and the only words that can be pronounced are Laura, for Laura, on Laura. Laura becomes poetry, poetry becomes Laura: Laura/lauro, laurel wreath; Laura and life become one: Laura/ aura, air. The pestis phantasmatum-the overwhelming animi passionem of which Augustinus speaks in the Secretum impedes Petrarch's journey towards his animi tranquillitas, which is to say towards salvation-is melancholy. A melancholy that pervades all of Petrarch's Canzoniere, and constitutes its most fundamental trait. Augustinus, as a Christian, considers Laura the cause of this repugnant pestis, to which the human being is exposed when he or she draws away from true images of good. Thus Augustinus insists that Franciscus must abandon immediately and without hesitation this nefarious passion. Petrarch cannot obey; he cannot abandon that image of desire. Laura has become the proton organon, the only element capable of simulating in a somatic language the language of the spirit. In other words, to speak what can never be spoken, that is to say to make poetry.

14 At this point, several questions come to mind: first, to what extent was Petrarch lucid about the human propensity to conflate desire with the good and saw it as a problem in the sonnets themselves? And if he was aware of this propensity and saw it as a problem, is there not a painful dimension to his poetry, one that recognizes a problem but cannot address it? The second question concerns Petrarch's attitude towards Dante's moral imperative that in a Christian world the only object of desire must be the Summum Bonum, the ultimate good; finally, is desire in Petrarch but a less dramatic version of desire in Guido Cavalcanti, or is it different kind of experience? 
